\title{
JOURNAL.RU
}

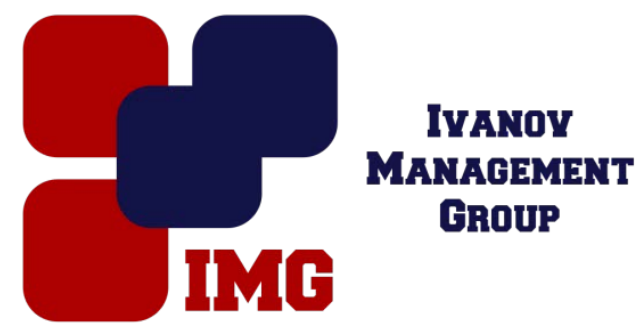

Марухно B.M. ФГБОУ ВПО «КубГАУ»

doi: 10.18411/lj-31-01-2017-4-10

idsp 000001:lj-31-01-2017-4-10

\section{К вопросу о разделе наследственного имущества}

\section{Аннотация}

В данной работе автор рассматривает особенности раздела наследственного имущества, систематизированы основания возникновения преимущественного права на определенное имущество из состава наследства.

Ключевые слова: наследование, завещание, наследственное имущество, наследники.

\section{Maruhno V.M.}

\section{With regard to separation of inherited property}

\section{Annotation}

In this study the author deals with the peculiarities of separation of inherited property, it was systemized the basics of origin of priority right to particular property from estate.

Keywords: inheritance, testament, inherited property, heirs.

В соответствии со ст. 1164 ГК РФ, при наследовании по закону, если наследственное имущество переходит к двум или нескольким наследникам, и при наследовании по завещанию, если оно завещано двум или нескольким наследникам без указания наследуемого каждым их них конкретного имущества, наследственное имущество поступает со дня открытия наследства в общую долевую собственность наследников.Однако анализ действующего гражданского законодательства позволяет выделить некоторые особенности раздела наследства. Согласно положениям ст. 1166 ГК РФ, при наличии зачатого, но еще не родившегося наследника раздел наследства может быть осуществлен только после рождения такого наследника. Соответственно соглашение о разделе наследства, заключенное до рождения наследника, можно считать оспоримым в соответствии со ст. 168 ГК РФ. При наличии среди наследников несовершеннолетних, недееспособных или ограниченно дееспособных граждан, в целях охраны законных интересов указанных лицо составлении соглашения о разделе наследства и о рассмотрении в суде дела о 
разделе наследства должен быть уведомлен орган опеки и попечительства (ст. 37 ГК РФ).

При распределении имущества между наследникаминекоторым из них предоставлены преимущественные права на те или иные компоненты наследства для целей сохранения сложившихся к моменту открытия наследства стабильных и длительных отношений по владению и пользованию имуществом, а также для обеспечения его целевого использования или для обеспечения прав и законных интересов социально незащищенных лиц[1].В соответствии со ст. 1168 ГК РФК такому имуществу можно отнести: неделимые вещи, которые принадлежали на праве общей собственности наследнику и наследодателю; неделимые вещи, которыми пользовался наследник при жизни наследодателя; жилое помещение (жилой дом, квартира и тому подобное), не подлежащее разделу в натуре, в котором ко дню открытия наследства проживали наследники, не имеющие иного жилого помещения. При этом следует подчеркнуть, что наследники обладают преимущественным правом, но не обязанностью, следовательно, могут отказаться от осуществления преимущественного права при разделе наследства на получение в счет своей наследственной доли входящих в состав наследства неделимой вещи, раздел которого в натуре невозможен. В этом случае раздел наследства производится по общим правилам.

При разделе наследства, преимущественное право на получение в счет своей наследственной доли предметов обычной домашней обстановки и обихода имеет тот из наследников, кто проживал совместно с наследодателем на день открытия наследства (ст. 1169 ГК РФ). При этом, как указывают некоторые авторы, одного факта совместного проживания с наследодателем недостаточно. Исходя из толкования слова «обиход» представляется, что законодатель имел в виду только тех наследников, которые не только проживали с наследодателем, но и пользовались вместе с ним этими предметами для удовлетворения повседневных бытовых нужд. Таким образом, для приобретения указанных предметов закон не выделяет такого условия, как ведение с умершим общего хозяйства. Вещами можно пользоваться и без ведения общего хозяйства с собственником[2].

\section{Литература}

1. Абраменков М.С. Раздел наследственного имущества и оформление прав на него // Наследственное право. 2014. № 2. С. 5.

2. Кравчук А.Г., Мелихов В.М., Рыженков А.Я. Правовой режим наследования (вопросы теории и практики) // Под ред. А.Я. Рыженкова. - Волгоград: «Панорама», 2006. -С.86 